\title{
Systematic evaluation of cryptic freshwater snails from central Chile, including the enigmatic Littoridina santiagensis (Gastropoda, Truncatelloidea)
}

\author{
Gonzalo A. COLLADO ${ }^{1 *}$, Karina P. AGUAYO ${ }^{2}$, Néstor J. CAZZANIGA ${ }^{3}$, \\ Diego E. GUTIÉRREZ GREGORIC ${ }^{4}$, Micaela DE LUCÍA ${ }^{5} \&$ Martin HAASE $^{6}$ \\ ${ }^{1,2}$ Departamento de Ciencias Básicas, Facultad de Ciencias, Universidad del Bío-Bío, \\ Avenida Andrés Bello 720, Chillán, Chile. \\ ${ }^{3}$ Departamento de Biología Bioquímica y Farmacia, Universidad Nacional del Sur, \\ San Juan 670. 8000 Bahía Blanca, Argentina. \\ 4,5 División Zoología Invertebrados, Museo de La Plata, \\ Facultad de Ciencias Naturales y Museo, Universidad Nacional de La Plata, \\ Paseo del Bosque $\mathrm{s} / \mathrm{n}^{\circ}$, La Plata, Buenos Aires, B1900WFA, Argentina. \\ ${ }^{6}$ Vogelwarte, Zoological Institute and Museum, University of Greifswald, \\ Soldmannstr. 23,17489 Greifswald, Germany. \\ *Corresponding author: gcollado@ubiobio.cl \\ 2Email: karina.aguayo.rosales@gmail.com \\ 33Email: ficazzan@criba.edu.ar \\ [4Email: dieguty@fcnym.unlp.edu.ar \\ ${ }^{5}$ Email: mecdl@hotmail.com \\ 6Email: mhaase@uni-greifswald.de

\footnotetext{
${ }^{1}$ urn:Isid:zoobank.org:author:04354188-59C0-4D39-B418-F13320D21A17

${ }^{2}$ urn:lsid:zoobank.org:author:3A2EDEF7-A8D6-4755-8535-75C8D0D53E8F

${ }^{3}$ urn:1sid:zoobank.org:author:2EC19B39-ED0D-47AF-95AA-4AC32C616751

${ }^{4}$ urn:1sid:zoobank.org:author:97674DDC-A422-4E70-8106-2113D778EB0B

${ }^{5}$ urn:1sid:zoobank.org:author:C8D15276-9582-4578-981F-18E40ED5A2CD

${ }^{6}$ urn:1sid:zoobank.org:author:8CE4B347-14C5-464F-99C4-DE2263FC55D5
}

\begin{abstract}
Walter Biese described Littoridina santiagensis Biese, 1944 (Cochliopidae) from Estero Dehesa in 1944 based exclusively on external shell features and a second allopatric population in Yeso Spring three years later. Since 2011 different samplings have been carried out at the type locality and have only provided specimens of the morphologically similar invasive mudsnail Potamopyrgus antipodarum Gray, 1843 (Tateidae), raising doubts about the identity of the species. The recent finding of two snail morphotypes in Yeso Spring, a thick shelled form congruent with type specimens of L. santiagensis and a slender one morphologically associable to $P$. antipodarum, allowed comparative studies, including the taxonomic analysis of additional populations with similar shell morphology occurring in central Chile. A DNA barcoding (COI) approach identified the slender form from Yeso Spring in Maipo Basin and a second population from the contiguous Rapel Basin indeed as the invasive P. antipodarum; however,
\end{abstract}


L. santiagensis was recovered among species of Potamolithus Pilsbry, 1896 (Tateidae), justifying the Potamolithus santiagensis (Biese, 1944) comb. nov. Besides recognition of three other populations as belonging to Potamolithus, the molecular analysis also suggests trans-Andean dispersal of this group of snails in the Southern Cone of South America.

Keywords. Cryptic species, freshwater snails, Cochliopidae, new combination, Tateidae.

Collado G.A., Aguayo K.P., Cazzaniga N.J., Gutiérrez Gregoric D.E., de Lucía M. \& Haase M. 2019. Systematic evaluation of cryptic freshwater snails from central Chile, including the enigmatic Littoridina santiagensis (Gastropoda, Truncatelloidea). European Journal of Taxonomy 524: 1-15. https://doi.org/10.5852/ejt.2019.524

\section{Introduction}

The taxonomic placement of minute Chilean freshwater snails solely described based on morphological characters, such as Littoridina santiagensis Biese, 1944, is rather controversial. This species was described in the genus Littoridina Souleyet, 1852 by Walter Biese from Estero Dehesa, a small tributary of the Mapocho River located east of Santiago in the Maipo Basin, based on characteristics of the shell and for which only a single drawing is available from the original description (Biese 1944) (Fig. 1). Along with similar forms, Biese related L. santiagensis to the Littoridina hatcheri Pilsbry, 1911 group, a species subsequently transferred to the genus Heleobia Stimpson, 1865 within the family Cochliopidae (Hershler \& Thompson 1992), but now recognized as member of the family Tateidae, closely related to the genus Potamolithus Pilsbry, 1896 (Koch et al. 2015). Shortly after the original publication, Biese (1947) discovered a second allopatric population in a spring tributary of the Yeso River, $55 \mathrm{~km}$ south of the type locality, which he assigned to L. santiagensis using the same typological criteria. Subsequent finds of the species have not been made, but it was cited by Stuardo (1961) in one of the most important checklists of Chilean freshwater mollusks of the 20th century. Later, Hershler \& Thompson (1992), in their influential work on Cochliopinae, placed all the Chilean species of Littoridina, including L. santiagensis, in the genus Heleobia, but without providing arguments for this translocation. This was perhaps one of the reasons why several authors continued to consider these species as members of Littoridina (e.g., Sielfeld 2001; Valdovinos 1999, 2006, 2008).

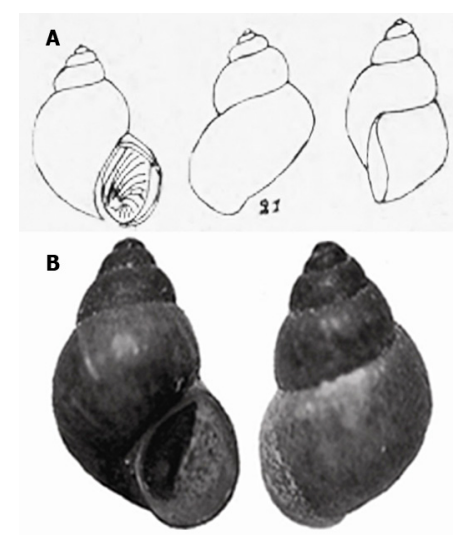

Fig. 1. "Littoridina" santiagensis Biese, 1944. A. The only drawings of a specimen of the species taken from the original description by Biese (1944). B. Lectotype housed at the Museo Nacional de Historia Natural, Santiago, Chile (MNHNCL) (after Collado et al. 2011). 
COLLADO G.A. et al., Systematic evaluation of cryptic freshwater snails

During a study of Chilean freshwater snails performed by the first author in 2011, specimens of L. santiagensis were not found at its type locality but specimens attributable to the species were found in Yeso Spring (Collado et al. 2011). Based on anatomical characters of the male copulatory organ, the authors moved the Chilean species of Littoridina to the genus Heleobia, although in the case of L. santiagensis this was not justified because no males were found among the specimens from that locality. More recently, a molecular phylogenetic analysis based on DNA sequences of the mitochondrial gene cytochrome oxidase subunit I (COI) obtained from snails collected from Estero Dehesa identified these specimens as the New Zealand mudsnail Potamopyrgus antipodarum (Gray, 1843) in the family Tateidae (Collado 2014), which is morphologically similar to L. santiagensis, suggesting either species displacement or an early misidentification of these snails as members of the genus Littoridina. The absence of males in snails examined from Yeso Spring (Collado et al. 2011) also contributed to raise doubts about the identity of this species, since the genera Littoridina and Heleobia contain dioecious species (e.g. Hubendick 1955; Gaillard \& de Castellanos 1976; Cazzaniga 1980, 1982a, 1982b; Hershler \& Thompson 1992; Collado et al. 2011; Ovando \& De Francesco 2011; Collado 2012, 2015).

New collections at the type locality (Estero Dehesa) of L. santiagensis in 2014, 2015 and 2017 have only been successful for $P$. antipodarum despite intensive sampling effort performed in different microhabitats (pers. obs.). On the other hand, two morphotypes were found in Yeso Spring, a slender form conferred to $P$. antipodarum and another thicker one provisionally assigned to L. santiagensis, taking into account the previous record by Biese and its morphological similarity regarding the type specimens of this species studied previously (Fig. 1) (Collado et al. 2011). Given the new material, in the present study we performed comparative studies between these snails and evaluated their systematic position based on morphological and molecular data, including other morphologically similar snail populations of uncertain taxonomic status found in central Chile.

\section{Material and methods}

The snails were collected from Estero Dehesa $\left(33^{\circ} 21^{\prime} 58.49^{\prime \prime} \mathrm{S}, 70^{\circ} 31^{\prime} 15.70^{\prime \prime} \mathrm{W}\right)$ and Yeso Spring

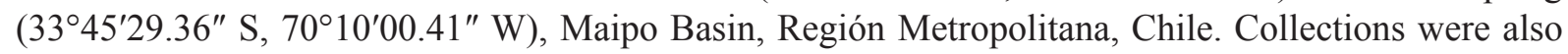
performed at three other localities harboring populations with a similar shell morphology, the irrigation canal Lo Carreño (343' $45^{\prime \prime} \mathrm{S}, 70^{\circ} 55^{\prime} 47.8^{\prime \prime} \mathrm{W}$ ) in the Región de O'Higgins, located about $143 \mathrm{~km}$ south of Estero Dehesa, two populations from the Región del Maule, Viña Casas del Maule (35 $33^{\prime} 04.37^{\prime \prime}$ S, $\left.71^{\circ} 40^{\prime} 12.25^{\prime \prime} \mathrm{W}\right)$, located about $265 \mathrm{~km}$ south of Estero Dehesa, and El Colorado, located about $50 \mathrm{~km}$ southeast of Viña Casas del Maule. To study the gross morphology, specimens were photographed using a Motic SMZ-168 stereo microscope provided with a Moticam 2000 digital camera and then compared with standard specimens of known taxonomic allocation (Collado 2014, 2016), type specimens or drawings of them (Pilsbry 1911; Biese 1944, 1947). The following measurements were taken on 95 snails: shell length (SL), shell width (SW), aperture length (AL), aperture width (AW), body whorl length (BWL) and spire length (SPL). Shell variables were logarithmically transformed for statistical analyses. Since variables were partly non-normally distributed and had inhomogeneous variances, we performed non-parametric Kruskal-Wallis tests and post-hoc pairwise Mann-Whitney U-tests for comparisons in STATISTICA ver. 7.0 (StatSoft Inc. 2004). A principal component analysis (PCA) was performed to visualize the morphological variation of different populations. Protoconchs, radulae and opercula were isolated and cleaned in a diluted sodium hypochlorite solution and then observed using a Hitachi SU3500 scanning electron microscope (SEM). Voucher specimens were deposited in the Museo de Ciencias Naturales Profesor Pedro Ramírez Fuentes (MCNPPRF 139-11 to 139-21), Chillán, Chile.

DNA extraction and amplification of partial sequences of the COI gene were performed following Collado (2014) using the new pair of primers ATCTGGTTTAGTRGGRACA (forward) and CCTGCYAAAACAGGYAAAG (reverse). The new sequences were deposited in GenBank (MH536524-MH536536). Genetic uncorrected p-distances were estimated in MEGA v.7.0 (Kumar 
et al. 2016). An initial BLASTn-analysis against the data base of GenBank confirmed that the species in question belonged to Tateidae. We also performed a Bayesian tree-based barcoding approach (Erickson \& Driskell 2012) to assess the familial/generic allocation of the species analyzed together with representative species of these families retrieved from GenBank (Hershler et al. 1999; Haase 2005; Kroll et al. 2012; Hamada et al. 2013; Wilke et al. 2013; Koch et al. 2015; Collado et al. 2016a; de Lucía \& Gutiérrez Gregoric 2017; Colgan \& da Costa, unpublished data). As COI was highly saturated across both families as shown by the test of Xia et al. (2003), our analysis was not supposed to reflect accurate relationships, but it allowed us to assign the Chilean species to their respective families and genera. We constructed a Bayesian tree using MrBayes ver.3.2.2 (Ronquist et al. 2011) based on the HKY $+\mathrm{I}+\Gamma$ substitution model identified as best fitting by jModelTest ver.2.1.4 (Darriba et al. 2012) according to all four criteria implemented in this program. MrBayes was run for 2 Mio generations with a burn-in of $25 \%$. In order not to aggravate the saturation problem by introducing an outgroup, the tree was midpoint rooted in FigTree ver.1.4.3 (http://tree.bio.ed.ac.uk/software/figtree/). For further comparison, we also obtained sequences of two specimens of Potamolithus from Puerto Chico, Llanquihue Lake, Región de Los Lagos $\left(41^{\circ} 19^{\prime} 37.06^{\prime \prime} \mathrm{S} ; 7^{\circ} 57^{\prime} 26.64^{\prime \prime} \mathrm{W}\right)$, the type locality of $P$. australis Biese, 1944, the only species of the genus reported from Chile. However, as it has been considered a nomen dubium (López Armengol 1985), we treat these snails as Potamolithus sp. until a formal redescription may be established.

\title{
Results
}

\section{Species delimitation}

The classification of specimens based on external shell features was difficult to perform in the field. Under magnification, two snail morphotypes could be recognized in Yeso Spring and Lo Carreño, a slender form morphologically associable to $P$. antipodarum and a thick-shelled one congruent with the type specimens of $L$. santiagensis, here transferred to Potamolithus based on anatomical characters and DNA barcode analysis (see below). The thicker-shelled specimens from El Colorado and Viña Casas del Maule were assigned to Potamolithus as well (Fig. 2).

\author{
Superfamily Truncatelloidea Gray, 1840 \\ Family Tateidae Thiele, 1925 \\ Genus Potamolithus Pilsbry, 1896
}

Type species: Paludina lapidum d'Orbigny, 1835, by subsequent designation.

Potamolithus santiagensis (Biese, 1944) comb. nov.

Figs $1-5$

Littoridina santiagensis Biese, 1944: 187-188, fig. 21 (Estero Dehesa, Cerro Manquehue, Barnechea, east to Santiago, Chile, type locality).

Littoridina santiagensis-Stuardo, 1961: 17. —Valdovinos, 1999: 128, 2006: 90. —Sielfeld, 2001: 3.

Heleobia santiagensis (Biese, 1944). Hershler \&Thompson, 1992: 55. — Collado et al., 2011: 51, 54-56, fig. 2R-S.

\section{Type material}

\section{Lectotype}

CHILE • Santiago; 200611, MNHNCL (Collado et al. 2011). 


\section{Description}

SHELL. Ovate-conic, dark brown, relatively thick, with about 5.5 whorls (Fig. 3A-D). Shell length about $3.0 \mathrm{~mm}$ (Table 1). Periostracum brown. Protoconch smooth (Fig. 3E), with about 1.3 whorls and $400 \mu \mathrm{m}$ length $( \pm 10 \mu \mathrm{m}$ of standard deviation, $\mathrm{n}=9)$. Aperture ovate, slightly angled adapically, lip thickened. Umbilicus imperforate or absent. Operculum ovate, thin, multispiral, light brown-transparent, with eccentric nucleus (Fig. 3F-G); attachment scar occupying almost half of the internal surface (Fig. 3G). Mantle black with a conspicuous gray band on anterior margin, head black, somewhat depigmented in center (Fig. 3H-I). Foot black.

Females. With nuchal node, white lips, tentacles grayish or black (Fig. 3H-I). Some specimens with a white band at base of tentacles where eyes are located. Males were not observed.

RAdULA. Taenioglossate (formula 3-1-3), with two marginal teeth and a lateral tooth placed on each side of the central tooth (Fig. 3J-K). Central tooth trapezoidal, dorsally concave, ca. $20 \mu \mathrm{m}$ wide; basal tongue U-shaped; with 5-6 lateral cusps on each side of median cusp and 3-4 pairs of basal cusps, first basal cusps arise from tooth face and are larger than those on cutting edge. Median cusp of central tooth

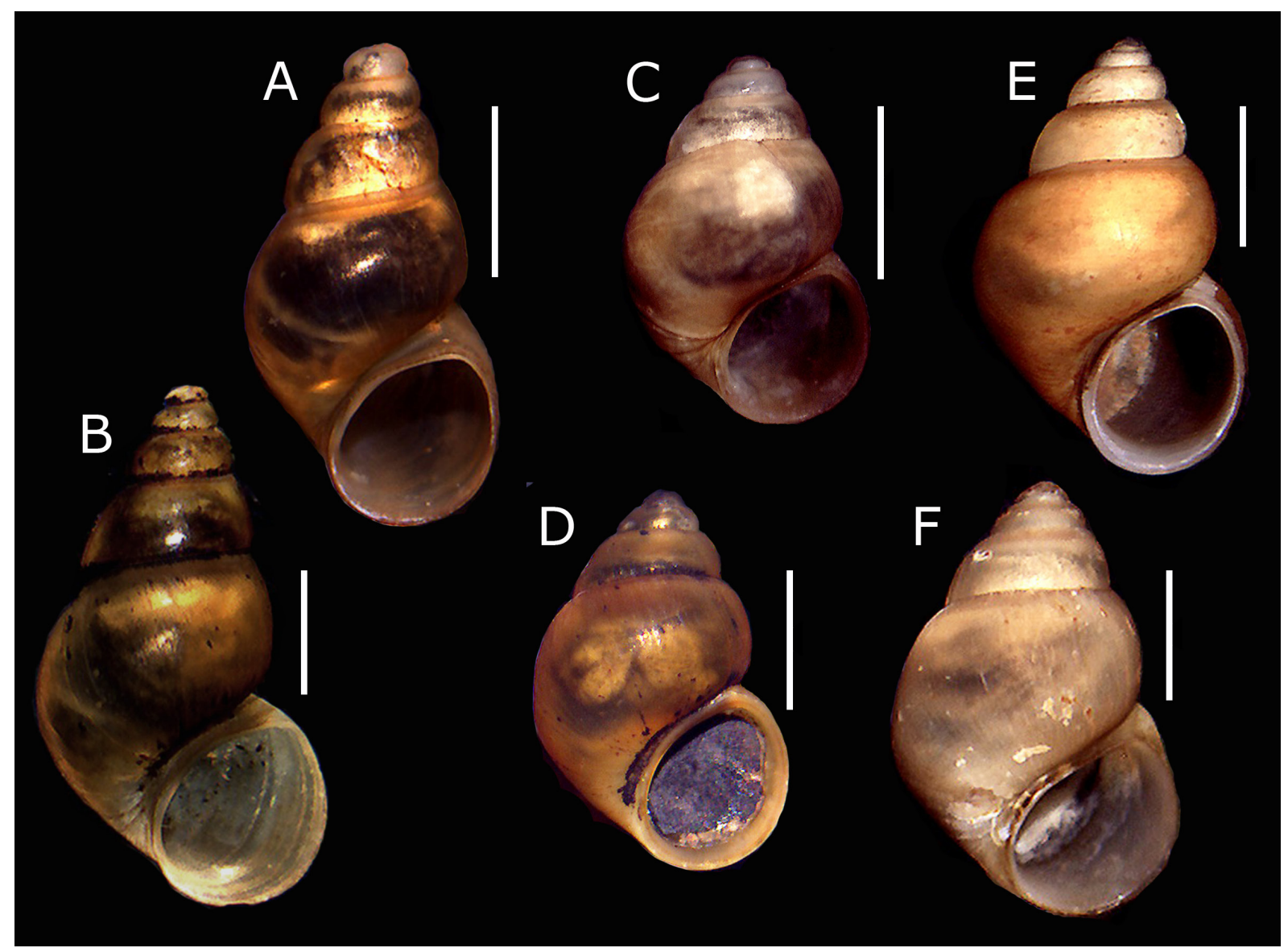

Fig. 2. Shells of truncatelloidean freshwater snails observed in the present study. A-B. Slender morphotype from El Yeso Spring (A) and Lo Carreño (B) assigned to Potamopyrgus antipodarum (Gray, 1843). C-E. Thicker morphotype from El Yeso Spring (C), Lo Carreño (D) and El Colorado (E) assigned to Potamolithus santiagensis (Biese, 1944) comb. nov. F. Thicker morphotype from Viña Casas del Maule assigned to Potamolithus sp. Scale bar $=1 \mathrm{~mm}$. 
well-developed and pointed. Lateral tooth with 11 cusps and median cusp well-developed and pointed. Inner marginal teeth with about 30 cusps (Fig. 3K).

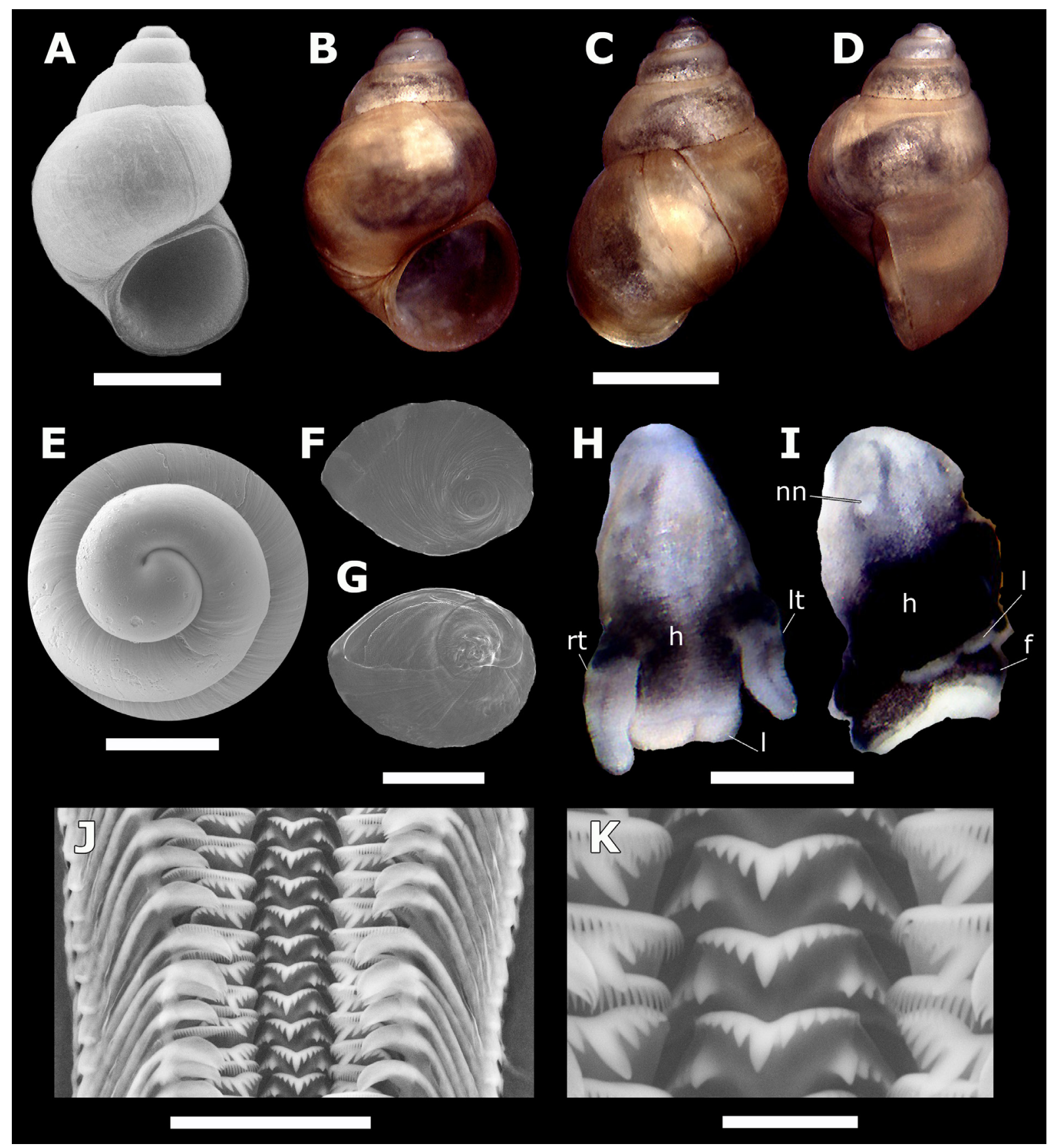

Fig. 3. Potamolithus santiagensis (Biese, 1944) comb. nov., Yeso Spring, Chile. A. Shell imaged using SEM. B-D. Shell of the same specimen photographed under a stereo microscope (frontal, dorsal, lateral views). E. Protoconch. F-G. Opercula of two specimens (outer, inner sides, respectively). H. Head of a female. I. Head of another female having a nuchal node. J. Anterior-central section of radular ribbon. K. Central teeth. Abbreviations: $\mathrm{f}=$ foot; $\mathrm{h}=$ head; $1=$ lip; $\mathrm{lt}=$ left tentacle; $\mathrm{nn}=$ nuchal node; $\mathrm{rt}=$ right tentacle. Scale bars: $A-D=1.0 \mathrm{~mm} ; \mathrm{E}=250 \mu \mathrm{m} ; \mathrm{F}-\mathrm{G}=500 \mu \mathrm{m} ; \mathrm{H}-\mathrm{I}=0.5 \mathrm{~mm} ; \mathrm{J}=50 \mu \mathrm{m} ; \mathrm{K}=10 \mu \mathrm{m}$. 


\section{Ecology}

Potamolithus santiagensis comb. nov. is a herbivorous-detritivorous species that inhabits small water bodies like springs and small streams.

\section{Distribution}

Yeso Spring in Cajón del Maipo, Región Metropolitana, Central Chile (Biese 1947; Collado et al. 2011; present study). This spring is a small tributary of the Yeso River, which empties in the Maipo River. The species also inhabits small irrigation canals in the Región de O'Higgins (Lo Carreño) and Región del Maule (El Colorado). Snail collections made in 2011, 2014, 2015 and 2017 at the type locality Estero Dehesa have not provided specimens of the species. This ecosystem has been invaded by P. antipodarum (Collado 2014) and Physa sp. (unpublished data). In Yeso Spring, P. santiagensis comb. nov. coexists with $P$. antipodarum and snails of the genus Chilina Gray, 1828.

\section{Morphometric analysis}

The mean values of the shell variables obtained for the freshwater snails inhabiting central Chile are shown in Table 1. Although the Kruskal-Wallis tests considering the six variables analyzed were statistically significant, only 23 of 60 pairwise post-hoc comparisons among native Potamolithus populations and $P$. antipodarum were significant, providing evidence of the difficulties in distinguishing these snails (Table 2). However, in the PCA the Potamolithus populations were well separated from P. antipodarum

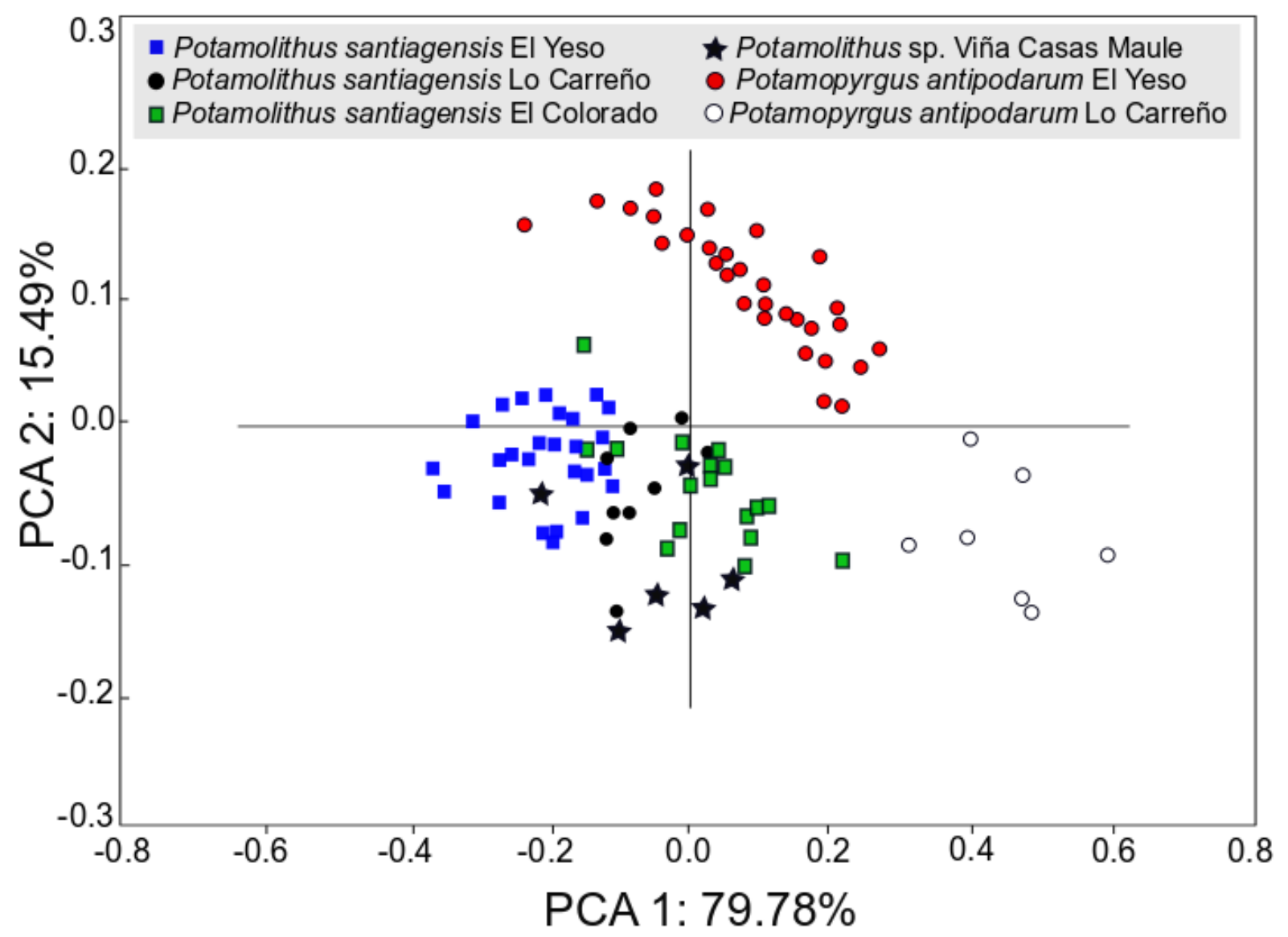

Fig. 4. PCA of Potamolithus populations and Potamopyrgus antipodarum (Gray, 1843) collected from central Chile. 
Table 1. Average shell dimensions ( \pm standard deviation) of six linear variables used in the comparative study of Potamolithus populations and Potamopyrgus antipodarum (Gray, 1843) from central Chile.

\begin{tabular}{lcccccc}
\hline Shell variable & n & SW & AL & AW & BWL & SPL \\
\hline $\begin{array}{l}\text { P. santiagensis comb. nov. } \\
\text { El Yeso }\end{array}$ & 26 & $1.7( \pm 0.1)$ & $1.3( \pm 0.1)$ & $0.9( \pm 0.1)$ & $2.1( \pm 0.1)$ & $0.6( \pm 0.1)$ \\
$\begin{array}{l}\text { P. santiagensis comb. nov. } \\
\text { El Colorado }\end{array}$ & 17 & $1.9( \pm 0.1)$ & $1.6( \pm 0.1)$ & $1.1( \pm 0.1)$ & $2.4( \pm 0.2)$ & $0.9( \pm 0.1)$ \\
$\begin{array}{l}\text { P. santiagensis comb. nov. } \\
\text { Lo Carreño }\end{array}$ & 9 & $1.7( \pm 0.1)$ & $1.3( \pm 0.1)$ & $1.2( \pm 0.1)$ & $2.1( \pm 0.1)$ & $0.8( \pm 0.1)$ \\
$\begin{array}{l}\text { Potamolithus sp. } \\
\text { Viña Casas del Maule }\end{array}$ & 6 & $2.0( \pm 0.1)$ & $1.6( \pm 0.2)$ & $1.1( \pm 0.1)$ & $2.4( \pm 0.2)$ & $0.7( \pm 0.1)$ \\
$\begin{array}{l}\text { P. antipodarum El Yeso } \\
\text { P. antipodarum Lo Carreño }\end{array}$ & 30 & $1.8( \pm 0.2)$ & $1.4( \pm 0.1)$ & $1.0( \pm 0.1)$ & $2.2( \pm 0.2)$ & $1.2( \pm 0.1)$ \\
& 7 & $2.6( \pm 0.2)$ & $2.1( \pm 0.2)$ & $1.4( \pm 0.1)$ & $3.2( \pm 0.2)$ & $1.7( \pm 0.3)$
\end{tabular}

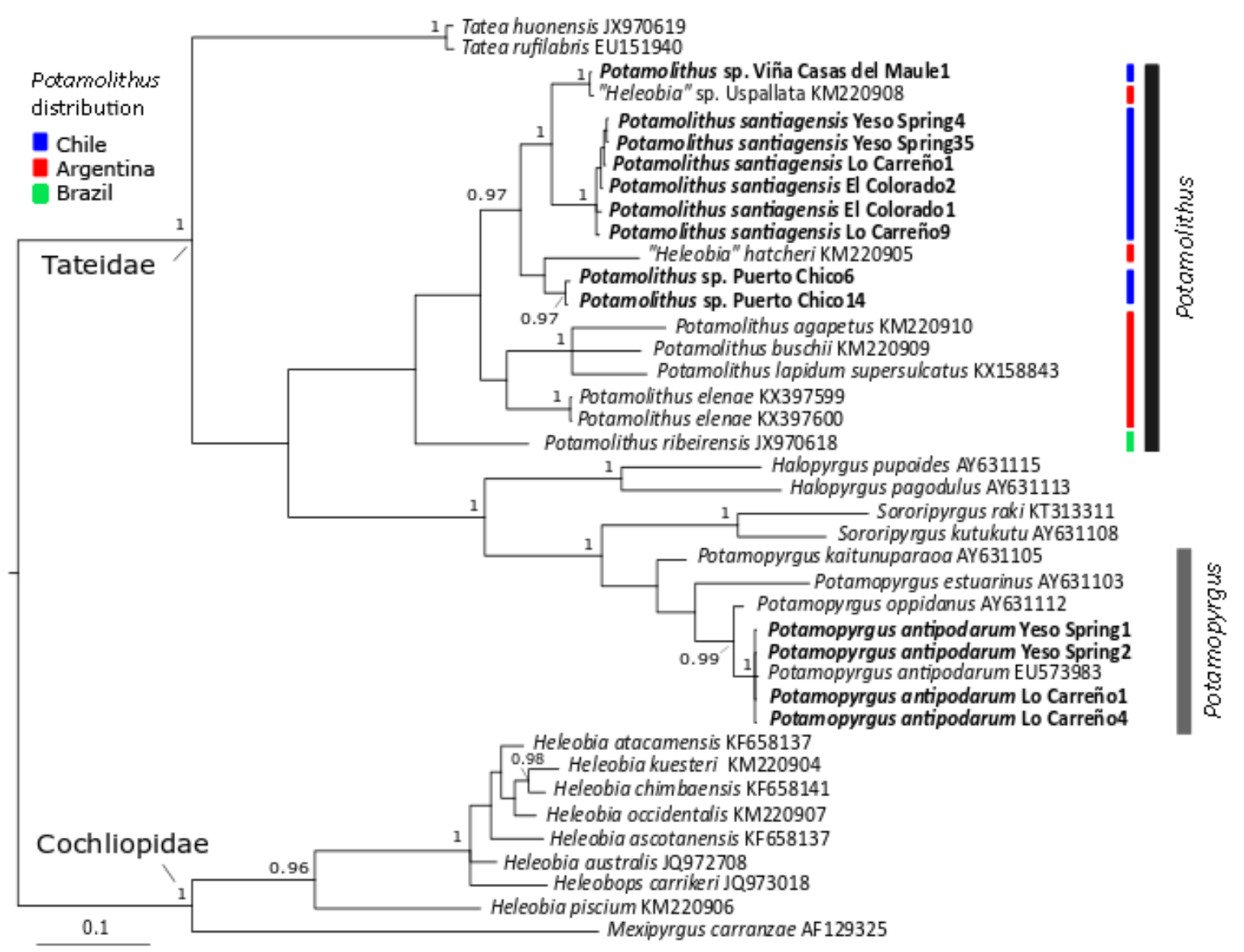

Fig. 5. Bayesian tree based on COI sequences. Numbers at nodes indicate posterior probability values (only given if $\geq 0.95$ ). Names in bold refer to new sequences reported in this paper. Numbers following taxa refer to GenBank sequences. 
COLLADO G.A. et al., Systematic evaluation of cryptic freshwater snails

in the morphometric space (Fig. 4). In this analysis, the first two components accounted cumulatively for $95.27 \%$ of the variance (PC1: $79.78 \%$; PC2: $15.49 \%$ ).

\section{Molecular analysis}

The COI phylogenetic analysis grouped the original sequences and those downloaded from GenBank into two main clades, Tateidae and Cochliopidae, respectively, both supported by posterior probabilities (p.p.) of 1.00 (Fig. 5). Our original sequences clustered in the first clade, either in the genus Potamolithus or Potamopyrgus, both groups inferred with high node support (0.97 and 1.00 p.p., respectively). The sequences of the slender morphotype from El Yeso Spring and Lo Carreño were identified as P. antipodarum, and those of the thicker one as representatives of Potamolithus (Fig. 5). The snails from El Colorado, Viña Casas del Maule, Puerto Chico, "Heleobia" sp. from Uspallata and "Heleobia" hatcheri from Aguas Negras in Argentina retrieved from GenBank were also recovered among Potamolithus species. The COI genetic distances among Tateidae species/populations from South America ranged between $0.2 \%$ and $17.0 \%$ (Table 3). The genetic distances between P. santiagensis comb. nov. and snails from Puerto Chico were estimated at 6.7-7.2\%. In the Bayesian tree, they were placed in different subclades. The population from Viña Casas del Maule grouped with "Heleobia" sp. from Uspallata (1.00 p.p.); they differed genetically from P. santiagensis comb. nov. by about $5.0 \%$. On the other hand, the sequence divergence between the population from El Colorado and P. santiagensis comb. nov. from Yeso Spring and Lo Carreño was low $(0.0-0.6 \%)$.

\section{Discussion}

The minute native gilled freshwater snails in Chile, at present placed in the genera Littoridina, Heleobia or Potamolithus, have had a complicated taxonomic history, as they have been ascribed to the families Amnicolidae, Hydrobiidae, Littoridinidae and Cochliopidae (e.g., Pilsbry 1911; Biese 1944, 1947; Hershler \& Thompson 1992; Valdovinos 1999, 2006; Figueroa et al. 1999; Sielfeld 2001). In Argentina, the taxonomic position of some species traditionally recognized as representatives of the genus Heleobia (Cochliopidae) as members of the family Tateidae has recently been discussed by different authors (Koch et al. 2015; de Lucía \& Gutiérrez Gregoric 2017). In the present study, the tree-based barcoding analysis provided evidence to transfer Littoridina/Heleobia santiagensis to the genus Potamolithus (Tateidae). The presence of a nuchal node, also observed in females of several species of this genus (Davis \& Pons da Silva 1984; López Armengol 1996; Pons da Silva \& Veitenheimer-Mendes 2004a), absent in Heleobia, is a morphological character that also supports this change, although it is not a diagnostic character of the genus (Núñez 2017). The three or four pairs of basal cusps on the rachidian tooth characteristic of the tateid radula also distinguish this group from Heleobia species (Pons da Silva \& Veitenheimer-Mendes 2004a; Cazzaniga 2011; Koch et al. 2015; de Lucía \& Gutiérrez Gregoric 2017), which usually have only one pair of basal cusps, rarely two (Gaillard \& de Castellanos 1976; Pons da Silva \& Veitenheimer-Mendes 2004b; Collado et al. 2016b).

The Bayesian analysis revealed that part of the material from Lo Carreño and the population from El Colorado grouped with sequences of $P$. santiagensis comb. nov. from El Yeso Spring, so we assigned these snails to this species. In Lo Carreño we also identified the New Zealand mudsnail P. antipodarum, extending its invasive range to a new hydrological basin further south of the previously known distribution in the country (Collado 2014, 2016). Morphometric data subjected to PCA also separated Potamolithus populations and the New Zealand mudsnail. Taking into account that the presence of the New Zealand mudsnail has also been reported at several type localities of endemic species of Heleobia in the Región de Coquimbo (Biese 1944, 1947; Collado 2014), where they were previously confused (Collado et al. 2011), these cryptic snails could potentially also be discriminated using this simple methodology. Single shell dimensions may or may not be operational, though, since a number of comparisons were statistically undifferentiable. The Bayesian analysis also inferred the sequences of "Heleobia" sp. Uspallata and 
Table 2. P-values of Kruskal-Wallis (in column Shell variable) and pairwise post-hoc Mann-Whitney U-tests of six linear variables.

\begin{tabular}{|c|c|c|c|c|c|}
\hline Species/population & $\begin{array}{l}\text { Shell } \\
\text { variable }\end{array}$ & $\begin{array}{l}\text { P. santiagensis } \\
\text { (El Yeso) }\end{array}$ & $\begin{array}{l}\text { P. antipodarum } \\
\text { (El Yeso) }\end{array}$ & $\begin{array}{l}\text { P. santiagensis } \\
\text { (El Colorado) }\end{array}$ & $\begin{array}{l}\text { Potamolithus } \\
\text { sp. (VCM) }\end{array}$ \\
\hline P. antipodarum (El Yeso) & \multirow{4}{*}{$\mathrm{SL}<0.001$} & $<0.001$ & & & \\
\hline P. santiagensis comb. nov. (El Colorado) & & $<0.001$ & 1.000 & & \\
\hline Potamolithus sp. (Viña Casas Maule) & & 0.068 & 1.000 & 1.000 & \\
\hline P. santiagensis comb. nov. (Lo Carreño) & & 0.379 & 0.236 & 1.000 & 1.000 \\
\hline P. antipodarum (El Yeso) & \multirow{4}{*}{$\mathrm{SW}<0.001$} & 1.000 & & & \\
\hline P. santiagensis comb. nov. (El Colorado) & & 0.001 & 0.003 & & \\
\hline Potamolithus sp. (Viña Casas Maule) & & 0.016 & 0.044 & 1.000 & \\
\hline P. santiagensis comb. nov. (Lo Carreño) & & 1.000 & 1.000 & 0.019 & 0.054 \\
\hline P. antipodarum (El Yeso) & \multirow{4}{*}{$\mathrm{AL}<0.001$} & 0.374 & & & \\
\hline P. santiagensis comb. nov. (El Colorado) & & $<0.001$ & $<0.001$ & & \\
\hline Potamolithus sp. (Viña Casas Maule) & & $<0.001$ & 0.029 & 1.000 & \\
\hline P. santiagensis comb. nov. (Lo Carreño) & & 1.000 & 1.000 & 0.022 & 0.151 \\
\hline P. antipodarum (El Yeso) & \multirow{4}{*}{$\mathrm{AW}<0.001$} & 1.000 & & & \\
\hline P. santiagensis comb. nov. (El Colorado) & & $<0.001$ & 0.008 & & \\
\hline Potamolithus sp. (Viña Casas Maule) & & 0.058 & 0.271 & 1.000 & \\
\hline P. santiagensis comb. nov. (Lo Carreño) & & $<0.001$ & $<0.001$ & 0.848 & 1.000 \\
\hline P. antipodarum (El Yeso) & \multirow{4}{*}{$\begin{array}{l}\text { BWL } \\
<0.016\end{array}$} & 0.511 & & & \\
\hline P. santiagensis comb. nov. (El Colorado) & & 0.002 & 0.361 & & \\
\hline Potamolithus sp. (Viña Casas Maule) & & 0.013 & 0.371 & 1.000 & \\
\hline P. santiagensis comb. nov. (Lo Carreño) & & 1.000 & 1.000 & 1.000 & 0.872 \\
\hline P. antipodarum (El Yeso) & \multirow{4}{*}{$\mathrm{SPL}<0.001$} & $<0.001$ & & & \\
\hline P. santiagensis comb. nov. (El Colorado) & & $<0.001$ & 0.038 & & \\
\hline Potamolithus sp. (Viña Casas Maule) & & 1.000 & 0.004 & 1.000 & \\
\hline P. santiagensis comb. nov. (Lo Carreño) & & 0.382 & 0.003 & 1.000 & 1.000 \\
\hline
\end{tabular}

"Heleobia" hatcheri from Argentina as members of the genus Potamolithus, representing other cases of familial and generic misidentification.

In the Southern Cone of South America, the close phylogenetic relationships found between samples of "Heleobia" hatcheri from the Central-West region of Argentina and Potamolithus sp. from Llanquihue Lake in the Chilean Patagonia suggests that dispersal across the Andes may have played a role in the distribution of these species. The same may be inferred regarding the Chilean Potamolithus populations from Viña Casas del Maule and "Heleobia" sp. from Uspallata, Argentina, and the lowland populations of $P$. santiagensis comb. nov., which exhibit disjunct distributions in Chile.

The New Zealand mudsnail has been considered as a highly invasive species worldwide (Son 2008; Alonso \& Castro-Díez 2012; Butkus et al. 2012), potentially able to seriously affect the native snail fauna in invaded aquatic ecosystems (Richards 2002). After this species arrived in the Snake River drainage in North America in 1987 (Bowler 1991), five native species were recorded as either "threatened" or "endangered", in part due to the introduction of the species (Richards 2002). It is possible that something similar has happened in Estero Dehesa considering the failure to find specimens of $P$. santiagensis 
Table 3. Percent of mean sequence variation (based on p-distance) of COI data among South American species/populations belonging to the Tateidae.

\begin{tabular}{|c|c|c|c|c|c|c|c|c|c|c|c|c|c|c|c|c|}
\hline Species/population & 1 & 2 & 3 & 4 & 5 & 6 & 7 & 8 & 9 & 10 & 11 & 12 & 13 & 14 & 15 & 16 \\
\hline $\begin{array}{l}\text { 1. Potamopyrgus antipodarum } \\
\text { El Yeso Spring } 1\end{array}$ & 0.0 & & & & & & & & & & & & & & & \\
\hline $\begin{array}{l}\text { 2. Potamopyrgus antipodarum } \\
\text { Lo Carreño } 1\end{array}$ & 0.0 & 0.0 & & & & & & & & & & & & & & \\
\hline 3. "Heleobia" hatcheri & 17.0 & 17.0 & 0.0 & & & & & & & & & & & & & \\
\hline 4. "Heleobia” sp. Uspallata & 14.5 & 14.5 & 8.2 & 0.0 & & & & & & & & & & & & \\
\hline 5. Potamolithus agapetus & 15.1 & 15.1 & 11.4 & 9.2 & 0.0 & & & & & & & & & & & \\
\hline 6. Potamolithus ribeirensis & 17.0 & 17.0 & 12.1 & 9.6 & 11.0 & 0.0 & & & & & & & & & & \\
\hline 7. Potamolithus buschii & 15.1 & 15.1 & 10.6 & 9.2 & 7.6 & 10.2 & 0.0 & & & & & & & & & \\
\hline 8. Potamolithus elenae 14191 & 15.3 & 15.3 & 9.0 & 7.0 & 8.8 & 9.4 & 6.8 & 0.0 & & & & & & & & \\
\hline $\begin{array}{l}\text { 9. Potamolithus santiagensis } \\
\text { El Yeso Spring } 4\end{array}$ & 15.3 & 15.3 & 9.0 & 5.3 & 10.2 & 10.8 & 10.4 & 9.0 & 0.0 & & & & & & & \\
\hline $\begin{array}{l}\text { 10. Potamolithus santiagensis } \\
\text { El Yeso Spring } 35\end{array}$ & 15.3 & 15.3 & 9.0 & 5.3 & 10.2 & 10.8 & 10.4 & 9.0 & 0.0 & 0.0 & & & & & & \\
\hline $\begin{array}{l}\text { 11. Potamolithus santiagensis } \\
\text { El Colorado } 1\end{array}$ & 15.3 & 15.3 & 8.6 & 5.1 & 10.0 & 10.4 & 10.4 & 8.6 & 0.6 & 0.6 & 0.0 & & & & & \\
\hline $\begin{array}{l}\text { 12. Potamolithus santiagensis } \\
\text { El Colorado } 2\end{array}$ & 15.3 & 15.3 & 9.0 & 5.3 & 10.2 & 10.8 & 10.4 & 9.0 & 0.0 & 0.0 & 0.6 & 0.0 & & & & \\
\hline $\begin{array}{l}\text { 13. Potamolithus santiagensis } \\
\text { Lo Carreño } 9\end{array}$ & 15.1 & 15.1 & 8.6 & 5.1 & 9.8 & 10.4 & 10.4 & 8.6 & 0.6 & 0.6 & 0.4 & 0.6 & 0.0 & & & \\
\hline $\begin{array}{l}\text { 14. Potamolithus santiagensis } \\
\text { Lo Carreño } 1\end{array}$ & 15.3 & 15.3 & 9.0 & 5.3 & 10.2 & 10.8 & 10.4 & 9.0 & 0.0 & 0.0 & 0.6 & 0.0 & 0.6 & 0.0 & & \\
\hline $\begin{array}{l}\text { 15. Potamolithus sp. Viña } \\
\text { Casas del Maule } 1\end{array}$ & 14.3 & 14.3 & 8.0 & 0.2 & 9.0 & 9.4 & 9.0 & 6.8 & 5.1 & 5.1 & 4.9 & 5.1 & 4.9 & 5.1 & 0.0 & \\
\hline $\begin{array}{l}\text { 16. Potamolithus sp. Puerto } \\
\text { Chico } 6\end{array}$ & 15.5 & 15.5 & 5.7 & 6.1 & 9.2 & 10.0 & 8.2 & 6.5 & 7.2 & 7.2 & 7.2 & 7.2 & 6.8 & 7.2 & 5.9 & 0.0 \\
\hline $\begin{array}{l}\text { 17. Potamolithus sp. Puerto } \\
\text { Chico } 14\end{array}$ & 15.3 & 15.3 & 5.5 & 5.9 & 9.0 & 9.8 & 8.0 & 6.3 & 7.0 & 7.0 & 7.0 & 7.0 & 6.7 & 7.0 & 5.7 & 0.2 \\
\hline
\end{tabular}

comb. nov. and the current occurrence of New Zealand mudsnails at this locality. Although without being alarmist, perhaps a "chronicle of a death foretold" could be written for the El Yeso Spring population based on the noticeable abundance of New Zealand mudsnails in this habitat compared to P. santiagensis comb. nov. In this context, the finding of the new populations of this species in El Colorado, where the New Zealand mudsnail has not been introduced, acquires real significance giving a light of hope for the preservation of the species.

\section{Acknowledgments}

We thank the staff of the Museo de Ciencias Naturales y Arqueología Profesor Pedro Ramírez Fuentes, Chillán, Chile. We also thank Francis Miño and Nicolás Villalobos for logistic support in the field and Cristian Suárez for assistance with the SEM observations. MdL is a fellow in Comision de Investigaciones Científicas de la Provincia de Buenos Aires and DEGG is a staff reasearcher in Consejo Nacional de Investigaciones Científicas y Técnicas (CONICET). NJC is a staff reasearcher in Comisión de Investigaciones Científicas de la Provincia de Buenos Aires. GAC is part of the Grupo de Biodiversidad y Cambio Global, Universidad del Bío-Bío. The authors also thank the CONICYT- 
FONDEQUIP Program (No. EQM-140088) and recognize the contribution of the anonymous reviewers. This paper was supported by CONICYT-FONDECYT 11130697.

\section{References}

Alonso Á. \& Castro-Díez P. 2012. The exotic aquatic mud snail Potamopyrgus antipodarum (Hydrobiidae, Mollusca): state of the art of a worldwide invasion. Aquatic Sciences 74: 375-383. https://doi.org/10.1007/s00027-012-0254-7

Biese W.A. 1944. Revisión de los moluscos terrestres y de agua dulce provistos de concha de Chile. Parte I, Familia Amnicolidae. Boletín del Museo Nacional de Historia Natural 22: 169-190.

Biese W.A. 1947. Revisión de los moluscos terrestres y de agua dulce provistos de concha de Chile. Parte II, Familia Amnicolidae (continuación). Boletín del Museo Nacional de Historia Natural 23: 63-77.

Bowler P.A. 1991. The rapid spread of the freshwater hydrobiid snail Potamopyrgus antipodarum (Gray) in the Middle Snake River, Southern Idaho. Proccedings of the Desert Fishes Council 21: 173-182.

Butkus R., Šidagyte E. \& Arbačiauskas K. 2012. Two morphotypes of the New Zealand mud snail Potamopyrgus antipodarum (J.E. Gray, 1843) (Mollusca: Hydrobiidae) invade Lithuanian lakes. Aquatic Invasions 7: 211-218. https://doi.org/10.3391/ai.2012.7.2.007

Cazzaniga N.J. 1980. Notas sobre los hidróbidos argentinos. I (Gastropoda: Rissoidea). Acerca de Littoridina occidentalis (Doering, 1884). Neotropica 26 (76): 187-191.

Cazzaniga N.J. 1982a. Notas sobre los hidróbidos argentinos. 5. Conquiliometría de Littoridina parchappii (d'Orbigny, 1835) (Gastropoda Rissoidea) referida a su ciclo de vida en poblaciones australes. Iheringia Série Zoologia 61: 97-118.

Cazzaniga N.J. 1982b. Nota sobre los hidróbidos argentinos. II (Gastropoda: Rissoidea). Una Littoridina del "grupo parchappii" en Península Valdés (Chubut). Revista del Museo de la Plata (Nueva Serie 13), Sección Zoología 129: 11-16.

Cazzaniga N.J. 2011. Heleobia Stimpson, 1865: Taxonomía. In: Cazzaniga N.J. (ed.) El género Heleobia (Caenogastropoda: Cochliopidae) en América del Sur. Amici Molluscarum, número especial: 12-17.

Collado G.A. 2012. Nuevo registro de distribución geográfica y antecedentes de historia natural de Heleobia chimbaensis (Biese, 1944) (Caenogastropoda: Cochliopidae) en la costa del desierto de Atacama: implicancias para su conservación. Amici Molluscarum 20(2): 13-18.

Collado G.A. 2014. Out of New Zealand: molecular identification of the highly invasive freshwater mollusk Potamopyrgus antipodarum (Gray, 1843) in South America. Zoological Studies 53: 70.

https://doi.org/10.1186/s40555-014-0070-y

Collado G.A. 2015. A new freshwater snail (Caenogastropoda: Cochliopidae) from the Atacama Desert, northern Chile. Zootaxa 3925 (3): 445-449. https://doi.org/10.11646/zootaxa.3925.3.9

Collado G.A., Méndez M.A., Letelier S., Veliz D. \& Sabando M.C. 2011. Morfología peniana y taxonomía del género Heleobia Stimpson, 1865 en Chile junto a una revisión de los ejemplares tipo del Museo Nacional de Historia Natural de Chile. In: Cazzaniga N.J. (ed.) El género Heleobia (Caenogastropoda, Cochliopidae) en América del Sur. Amici Molluscarum, número Especial: 49-58.

Collado G.A., Valladares M.A. \& Méndez M.A. 2016a. Unravelling cryptic species of freshwater snails (Caenogastropoda, Truncatelloidea) in the Loa River basin, Atacama Desert. Systematics and Biodiversity 14 (4): 417-429. https://doi.org/10.1080/14772000.2016.1153526

Collado G.A., Valladares M.A. \& Méndez M.A. 2016b. A new species of Heleobia (Caenogastropoda: Cochliopidae) from the Chilean Altiplano. Zootaxa 4137: 277-280.

https://doi.org/10.11646/zootaxa.4137.2.8 
COLLADO G.A. et al., Systematic evaluation of cryptic freshwater snails

Darriba D., Taboada G.L., Doallo R. \& Posada D. 2012. jModelTest 2: more models, new heuristics and parallel computing. Nature Methods 9: 772. https://doi.org/10.1038/nmeth.2109

Davis G.M. \& Pons da Silva M.C. 1984. Potamolithus: morphology, convergence and relationships among hydrobioid snails. Malacologia 25: 73-108.

de Lucía M. \& Gutiérrez Gregoric D.E. 2017. The genus Potamolithus Pilsbry, 1896 (Gastropoda: Tateidae) on the Somuncurá Plateau, Patagonia, Argentina. Molluscan Research 37 (3): 202-211. https://doi.org/10.1080/13235818.2017.1279476

Erickson D.L. \& Driskell A.C. 2012. Construction and analysis of phylogenetic trees using DNA barcode data. In: Kress W. \& Erickson D. (eds) DNA Barcodes. Methods in Molecular Biology 858: 395-408. Humana Press, Totowa, NJ. https://doi.org/10.1007/978-1-61779-591-6_19

Figueroa R., Araya E., Parra O. \& Valdovinos C. 1999. Macroinvertebrados bentónicos como indicadores de calidad de agua. In: Resúmenes Sexta Jornada del Comité Chileno para el Programa Hidrológico Internacional (CONAPHI): 1-24. Centro de Ciencias Ambientales, EULA, Concepción, Chile.

Gaillard M.C. \& de Castellanos Z.A. 1976. Moluscos Gasterópodos, Hydrobiidae. In: Ringuelet R.A. (ed.) Fauna de Agua dulce de la República Argentina 15 (2): 1-39, Buenos Aires Fundación para la Educación, la Ciencia y la Cultura (FECIC).

Haase M. 2005. Rapid and convergent evolution of parental care in hydrobiid gastropods from New Zealand. Journal of Evolutionary Biology 18: 1076-1086.

https://doi.org/10.1111/j.1420-9101.2005.00894.x

Hamada K., Tatara Y. \& Urabe M. 2013. Survey of mitochondrial DNA haplotypes of Potamopyrgus antipodarum (Caenogastropoda: Hydrobiidae) introduced into Japan. Limnology 14 (3): 223-228. https://doi.org/10.1007/s10201-013-0405-0

Hershler R. \& Thompson F.G. 1992. A review of the aquatic gastropod subfamily Cochliopinae (Prosobranchia: Hydrobiidae). Malacological Review, Supplement 5: 1-140.

Hershler R., Liu H.P. \& Mulvey M. 1999. Phylogenetic relationships within the aquatic snail genus Tryonia: implications for biogeography of the North American Southwest. Molecular Phylogenetics and Evolution 13 (2): 377-391. https://doi.org/10.1006/mpev.1999.0659

Hubendick B. 1955. XVIII. The anatomy of the Gastropoda. In: Gilson H.C. (ed.) The Percy Sladen Trust Expedition to Lake Titicaca in 1937 1: 309-327. Transactions of the Linnean Society, London.

Koch E., Martín S.M. \& Ciocco N.F. 2015. A molecular contribution to the controversial taxonomical status of some freshwater snails (Caenogastropoda: Rissooidea, Cochliopidae) from the Central Andes desert to Patagonia. Iheringia Série Zoologia 105: 69-75.

https://doi.org/10.1590/1678-4766201510516975

Kroll O., Hershler R., Albrecht C., Terrazas E.M., Apaza R., Fuentealba C. \& Wilke T. 2012. The endemic gastropod fauna of Lake Titicaca: correlation between molecular evolution and hydrographic history. Ecology and Evolution 2: 1517-1530. https://doi.org/10.1002/ece3.280

Kumar S., Stecher G. \& Tamura K. 2016. MEGA7: Molecular Evolutionary Genetics Analysis version 7.0 for bigger datasets. Molecular Biology and Evolution 33: 1870-1874.

https://doi.org/10.1093/molbev/msw054

López Armengol M.F. 1985. Estudio sistemático y bioecológico del Género Potamolithus (Hydrobiidae) utilizando Técnicas de Taxonomía numérica. Tesis Doctoral $\mathrm{N}^{\circ} 455$, Facultad Ciencias Naturales y Museo, Universidad Nacional de La Plata, La Plata, Argentina. 
López Armengol M.F. 1996. Taxonomic revision of Potamolithus agapetus Pilsbry, 1911, and Potamolithus buschii (Frauenfeld, 1865) (Gastropoda: Hydrobiidae). Malacologia 38: 1-17.

Núñez V. 2017. Redescription of Potamolithus paranensis (Pilsbry, 1911) and Potamolithus simplex (Pilsbry, 1911) (Gastropoda: Tateidae). Molluscan Research 37: 17-30.

https://doi.org/10.1080/13235818.2016.1201038

Ovando X.M.C. \& De Francesco C.G. 2011. El género Heleobia en el noroeste argentino. In: Cazzaniga N. J. (ed.) El género Heleobia (Caenogastropoda, Cochliopidae) en América del Sur. Amici Molluscarum, número especial: 22-25.

Pilsbry H.A. 1911. Non-marine Mollusca of Patagonia. In: Scott W.B. (ed.) Reports of the Princeton University Expedition to Patagonia 1896-1899. Part 5. Zoology: 513-633. The University of Princeton, Princeton, NJ.

Pons da Silva M.C. \& Veitenheimer-Mendes I.L. 2004a. Redescrição de Potamolithus catharinae com base em topotipos (Gastropoda, Hydrobiidae), rio Hercílio, Santa Catarina, Brasil. Iheringia Serie Zoologia 94: 83-88. https://doi.org/10.1590/S0073-47212004000100015

Pons da Silva M.C. \& Veitenheimer-Mendes I.L. 2004b. Nova espécie de Heleobia (Rissooidea, Hydrobiidae) da planicie costeira do sul do Brasil. Iheringia Série Zoologia 94 (1): 89-94.

https://doi.org/10.1590/S0073-47212004000100016

Richards D.C. 2002. The New Zealand mudsnail invades the Western United States. Aquatic Nuisance Species Digest 4: 42-44.

Ronquist F., Teslenko M., van der Mark P., Ayres D., Darling A., Höhna S., Larget B., Liu L., Suchard M.A. \& Huelsenbeck J.P. 2011. MrBayes 3.2: Efficient Bayesian phylogenetic inference and model choice across a large model space. Systematic Biology 61 (3): 539-542.

Sielfeld W. 2001. Phylum Mollusca. Guías de Identificación y Biodiversidad de la Fauna Chilena. Apuntes de Zoología. Universidad Arturo Prat, Iquique, Chile.

Son M.O. 2008. Rapid expansion of the New Zealand mud snail Potamopyrgus antipodarum (Gray, 1843) in the Azov-Black Sea Region. Aquatic Invasions 3: 335-340. https://doi.org/10.3391/ai.2008.3.3.9

StatSoft Inc. 2004. Statistica (data analysis software system), version 7. Available from https://www.statsoft.com [accessed 3 May 2018].

Stuardo J. 1961. Contribución a un catálogo de los moluscos gasterópodos chilenos de agua dulce. Gayana, Zoológica 1: 7-32.

Valdovinos C. 1999. Biodiversidad de moluscos chilenos: Base de datos taxonómica y distribucional. Gayana 63 (2): 111-164.

Valdovinos C. 2006. Estado de conocimiento de los gastrópodos dulceacuícolas de Chile. Gayana 70 (1): 88-95. https://doi.org/10.4067/S0717-65382006000100014

Valdovinos C. 2008. Invertebrados dulceacuícolas. In: CONAMA. Biodiversidad de Chile, Patrimonio y Desafios, Ocho Libros Editores: 201-225. Santiago, Chile.

Wilke T., Haase M., Hershler R., Liu H.P., Misof B. \& Ponder W. 2013. Pushing short DNA fragments to the limit: phylogenetic relationships of 'hydrobioid' gastropods (Caenogastropoda: Rissooidea). Molecular Phylogenetics and Evolution 66: 715-736. https://doi.org/10.1016/j.ympev.2012.10.025

Xia X., Xie Z., Salemi M., Chen L. \& Wang Y. 2003. An index of substitution saturation and its application. Molecular Phylogenetics and Evolution 26: 1-7.

https://doi.org/10.1016/S1055-7903(02)00326-3 
Manuscript received: 6 July 2018

Manuscript accepted: 31 January 2019

Published on: 14 May 2019

Topic editor: Rudy Jocqué

Desk editor: Marianne Salaün

Printed versions of all papers are also deposited in the libraries of the institutes that are members of the EJT consortium: Muséum national d'Histoire naturelle, Paris, France; Botanic Garden Meise, Belgium; Royal Museum for Central Africa, Tervuren, Belgium; Royal Belgian Institute of Natural Sciences, Brussels, Belgium; Natural History Museum of Denmark, Copenhagen, Denmark; Naturalis Biodiversity Center, Leiden, the Netherlands; Museo Nacional de Ciencias Naturales-CSIC, Madrid, Spain; Real Jardín Botánico de Madrid CSIC, Spain; Zoological Research Museum Alexander Koenig, Bonn, Germany. 